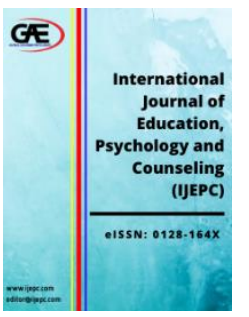

\author{
INTERNATIONAL JOURNAL OF \\ EDUCATION, PSYCHOLOGY \\ AND COUNSELLING \\ (IJEPC) \\ www.ijepc.com
}

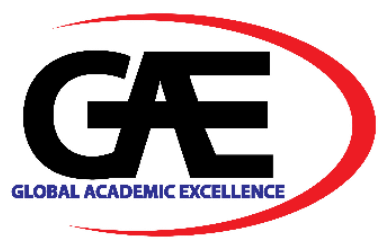

\title{
INFLUENCE OF ATTACHMENT STYLES ON ESTABLISHMENT OF ADOLESCENTS' SELF ESTEEM AMONG SECONDARY SCHOOL STUDENTS FROM BLENDED FAMILIES IN KIAMBU COUNTY
}

\author{
Lucy Gachenia $^{1 *}$, Ruth Kamunyu ${ }^{2}$, Nathan Chiroma ${ }^{3}$ \\ 1 Department of Psychology, Pan Africa Christian University, Kenya \\ Email: lucy.gachenia@pacuniversity.ac.ke \\ 2 Department of Psychology, Pan Africa Christian University, Kenya \\ Email: Ruth. Kamunyu@ pacuniversity.ac.ke \\ 3 Department of Children and Youth Ministry \\ Email: Nathan. Chiroma@ pacuniversity.ac.ke \\ Corresponding Author
}

\section{Article Info:}

Article history:

Received date: 19.04 .2021

Revised date: 30.04 .2021

Accepted date: 12.12.2021

Published date: 15.12 .2021

\section{To cite this document:}

Gachenia, L., Kamunyu, R., \& Chiroma, N. (2021). Influence Of Attachment Styles On Establishment Of Adolescents' Self Esteem Among Secondary School Students From Blended Families In Kiambu County. International Journal of Education, Psychology and Counseling, 6 (44), 176-197.

DOI: $10.35631 /$ IJEPC.644014

This work is licensed under CC BY 4.0

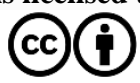

\section{Abstract:}

Attachment styles adopted by parents are essential in development of adolescent psychosocial wellbeing. This phenomenon is more profound in blended families where there are multiple relationships that can lead to many challenges. However, with appropriate attachment styles adopted by step parents such challenges can be mitigated. The purpose of this study was to assess the influence of attachment styles on adolescents' self-esteem among secondary school students from blended family in Kiambu County, Kenya. Attachment theory by Bowlby guided this study. The study adopted a mixed method approach, descriptive causal effect design and pragmatic paradigm to guide the study. Multi-stage sampling method and inclusive /exclusive criteria were used. Firstly the study adopted survey method as the sampling technique because the total population of adolescents that came from blended families was unknown. Simple random sampling was used to select 9 schools and also determine the 5 classes to be sampled in each of these schools. The 5 classes had a population of 55 students each. A short questionnaire with demographic data of students was issued to all the students (2475) in a bid to elicit the adolescents from the said classes that came from blended families in the 9 schools. A total number of 208 adolescents from blended families in the 9 schools was elicited and this was considered a sufficient sample size. In addition, simple random sampling was used to sample 24 respondents to form 4 focus groups while purposive sampling was used to sample 4 counsellors from 9 schools for in-depth interview. Data was collected using questionnaires, counsellors' interview schedule and focus group discussions. Inventory for 


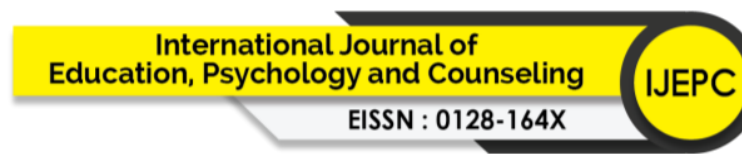

Volume 6 Issue 44 (December 2021) PP. 176-197

DOI 10.35631/IJEPC.644014

Parent and Peer Attachment Scale and Rosenberg Scales were used as measuring tools. Data was analysed through descriptive statistics, statistical assumption tests, correlation tests- T- test and ANOVA analysis while qualitative data was analysed by use of narrative analysis. Findings were presented in form of tables while interview data was presented in narrative form. Permission to conduct the study was obtained from the National Council for Science and Technology, the Kiambu County Government, Ethical approval was sought from accredited IERC (Institutional Ethics Review Committee) as well as a written informed consent from the school administration. Results indicated that attachment styles adopted by step parents influence the establishment of adolescent self- esteem. The study will benefit Ministry of Education, counsellors, parents, families and society.

Keywords:

Blended Families, Stepmother, Stepfather, Influence, Adolescents, Attachment Styles

\section{Introduction}

Parents who provide a warm, trustworthy secure base for adolescents are likely to bring up adolescents that depict a high self-esteem (Minev et al., 2018). On the contrary, if the parent adolescent relationship lack trust and communication, or is inconsistent, abusive and critical the adolescent has higher chances of developing a low self-esteem. The adolescent evaluation of self-concept lays a foundation for Global self-esteem (Erdvic et al., 2019). Global selfesteem is a comprehensive judgment of an individual's self- worth and self-acceptance (Erdvic et al, 2019). Adolescents usually have a low self-esteem due to the changes that they go through during adolescence period and sometimes because of comparing themselves with peers (Ksenija, 2016). Further, they also gauge themselves in regard to many facets and associations for instance friendships, education and athletic capabilities (Erdvic et al., 2019). Adolescents depict high self-esteem when they succeed in what they view crucial to them (Orth and Robin, 2014). While favourable self-assessment is related to positive adaptation and affability in adolescents of all classes, low self- esteem is connected to poor adjustment and depression (Orth \& Robin, 2015).

\section{Literature Review}

Lower levels of self-worth may be a predictor of unhappiness when adolescents mushroom into adults (Orth \&Robin, 2014). For instance, a longitudinal study was carried out where selfesteem was yearly assessed in about 1500 adolescents aged 12-15 years, findings indicated the age at which an adolescent was at the level of change in self-esteem were predictors of depression when individuals attain ages 16 to 35 (Steiger, Allemand, .Robins \& Fend, 2014) stipulated that children who transited to adolescence with low levels of self-esteem had their self-worth deflated further and this was a prediction of unhappiness twenty years later at adulthood.

During childhood years a care giver that forms a foundation of love, warmth and support towards the child enables them form a working model of the self as loveable and worthwhile (Allen and Loeb, 2015). Children that form mental representation of self easily individuate from early age and through to adolescence time and beyond (Young, 2013). This is enabled by the connection that the care giver had with the child when they were growing up (Shui, 2016). 


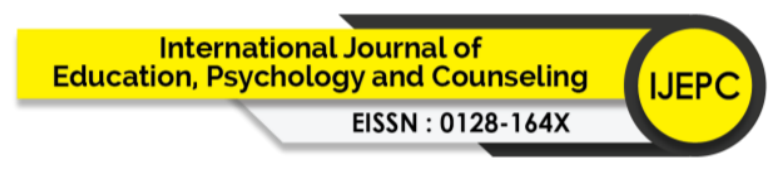

Volume 6 Issue 44 (December 2021) PP. 176-197

DOI 10.35631/IJEPC.644014

On the contrary, children who are renounced, uncared for and dominated fail to grow coherent working model (Shui, 2016).

According to (Pace \& Zapulla, 2011) a child sense of self thrives through a secure attachment relationship and matures into separation individuation where children are ready to separate from their care giver and develop their own identity; but still maintain close attachment relationships with the parent. In contrast, those children who are rejected, uncared for, over controlled by their primary care givers may not develop coherent working model of self (Pace \& Zappulla, 2011).

During adolescence the separation individuation manifests when they begin to feel autonomous and have a sense of self but remain emotionally attached to the attachment figure and trust in their availability and reliability (Pace \& Zappulla, 2011). Parent child attachment serve significant functions not only during infancy but also into adolescence and adulthood (Raudino, 2013).

Close connection with significant others especially parents are linked to higher degree levels of self-worth in youths which enhances their self-evaluation (Bi, 2018). For instance, a study done on teenagers from China, Germany, Australia and United States as well as Dutch, Turkish, Moroccan and Surinamese adolescents residing in Netherlands indicated that a close intimate teenager parent connection predicted self-esteem (Harris, 2015; Wang \& Sheikh, 2014). These studies were conducted in Western societies hence it was difficult to indicate the similarities or differences of the said results in the Kenyan context. One would have expected a change considering that parenting would differ. The current study sought to respond to the question 'Do parental attachment styles influence adolescent self-esteem?

Adolescent attachment should be a warm caring connection that includes feelings of trust, appropriate communication, and being supported by significant others (Keizer, 2019). Similarly (Young, 2013) agrees and supports this warm caring relationship (parental adolescent attachment bond) and adds that it gives a conducive environment which leads to high selfesteem in adolescent. Likewise, Colpina \& Veuschueren (2013) concurs that parents who provide a secure base that is characterized by warmth, encouragement and support often bring up adolescents with a high self-esteem.

Adolescents reliance on parental attachment figures lessens as they learn to develop new relationships with peers (Keizer, 2019) nevertheless it is argued that secure parental attachments are maintained to give an intimate supporting surrounding for adolescent to enhance liberation in a bid to expose them to the external world and this builds adolescents self-esteem (Allen, 2016). These findings concur to some extent with Young (2013) findings which stipulated that at adolescence stage, adolescents develop autonomy but remain emotionally attached to attachment figures for continuity and reliability. Moreover, care givers that permit growth of adolescent autonomy and still maintaining close interactions with them foster more positive feelings of self-worth than those in insecure relationships (Thompson, 2016). This shows how crucial parental connection is to teenagers. 


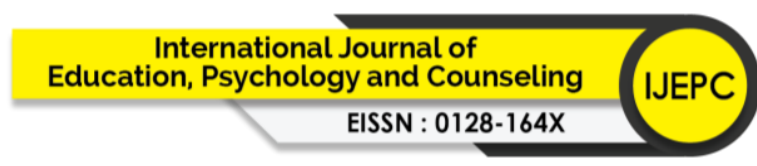

Volume 6 Issue 44 (December 2021) PP. 176-197

DOI 10.35631/IJEPC.644014

Adolescents whose parents adopt insecure attachment style suffer from a low self-esteem in comparison to those in secure attachments (Young, 2013). The above literature brought to the fore the importance of continued parental attachment in adolescent. The current study sought to establish how secure and insecure attachment styles influenced adolescent self-esteem.

Father- adolescent attachment style can often act as a secure base for adolescents (Lee \& Beckert, 2012). For instance, Allgood et al., (2012) examined how involved fathers were in their adolescent lives as well as their emerging adult daughters in relation to their self-esteem and psychological health. Their study findings showed that those daughters whose fathers were present in their lives had an increased self-esteem rating (Allgood et al., 2012). Moreover, daughters who perceived their fathers in a positive light also depicted high self-esteem than those who did not (Allgood et al., 2012). Similarly Keizer (2019) concur that fathers' attachment affect their adolescent daughters' self-esteem and out runs that of the mothers. In addition, fathers insecure attachment to their daughters have negative influence on their daughters psychosocial development which include; low self-esteem, social abilities and emotional monitoring (Jain, 2015). Mothers attachment is needed by children throughout their life time (Santrock et al., 2014) because this may guard adolescent from acquiring characteristics of low self-esteem (Anggraenni, 2019).

Attachment to both parents by adolescent is crucial for adolescent development for instance (Mónaco et al., 2019) suggest that adolescents that develop a secure relationship with both parents report strong emotional competence, higher satisfaction with life ,high self-esteem and less stress (Jiang \& Hills, 2013). Findings that (Boertien et al., 2017) concur with that such support has a positive influence on adolescents' satisfaction with life and their self-esteem. As noted above most previous studies had dwelt so much on paternal but not maternal attachment. The current study aimed at exploring step mother and step father attachment with adolescents separately because each parent is necessary in promoting the development of adolescent selfesteem.

Empirical studies have found that adolescent daughters report higher quality of attachment to both parents than adolescent sons (Zia et al., 2015). Moreover Keizer (2019) indicated that mother- child attachment are associated with higher levels of self-esteem for both adolescents' sons and daughters. Pertaining gender disparities longitudinal research found that adolescent girls self-esteem levels lower as they mature (Brown, 2015) in contrast to boys who tend to have increased self-esteem at adolescent stage (Rosen, 2016). The study sought to find out how step mother and step father attachment styles to adolescent boys and girls in the family affect their self-esteem.

Strong age group friendship is also related to heightened levels of self-esteem (O'Connor et al., 2011). Similarly other studies support this premise that peers also play an important part in that adolescents who feel appreciated and embraced by their peers depict high levels of selfesteem (Boertien \& Harkonen, 2017). In contrast those adolescents with low self-esteem display poor relationship with peers (Maunder \& Monks, 2018).

However, other studies refute this assertion that peer relationships are associated with adolescent self-esteem (Keizer,2019) For instance, in a study on perceived quality of parental attachment connection and adolescent self-esteem Keizer (2019) found out that changes in peer relationships had no relationship with adolescent self-esteem and that even though adolescent 


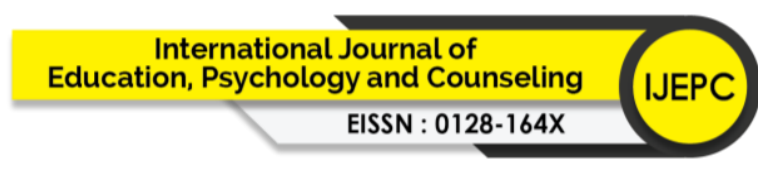

Volume 6 Issue 44 (December 2021) PP. 176-197

DOI 10.35631/IJEPC.644014

increase the time they spend with peers perceived changes parental attachment are highly significant in terms of how adolescents think of and judge themselves. This concurs with other earlier studies that the care giver continues to take up responsibility of creating a warm environment that fosters teenagers' growth in relation to self-worth and identity even when peer relationships become salient during adolescence stage (Laible et al., 2005).

These findings are similar to Bowlby's theory (Bowlby, 1971) that healthy relationships that adolescents have with parents are a manifestation of appropriate development . While the issues dealt with above are pertinent to the current study, they fall short of addressing the blended family and only concentrate on the nuclear family set up. A literature review on blended families show some advancement in exploration of family dynamics and processes that enhance step children adjustment (Jensen \& Harris, 2016). However, some gaps existed for instance many blended family studies focused more on wellbeing of young and pre-adolescent children with few having dealt on adolescent step children (e g; Amato, 2015; Jensen, 2015). In addition, few blended family studies had incorporated longitudinal data on self-esteem of step children and more so adolescent, moreover, step parent -children attachment had often been overlooked as a predictor of step adolescent self-esteem development (Jensen \& Harris, 2016).

To curb this void the objective of step parental attachment on adolescent self-esteem development in blended family became a key objective in this study. Previous empirical studies stipulate that secure step parent child relationship promote the wellbeing of step children and enhance the stability of step families (Howard \& Jensen, 2015).Similarly, Irankunda et al. (2018) agrees with this findings that close stepparents children relationships provide a conducive environment for adolescent to cope better and in turn promote their psychosocial wellbeing. Children in blended families have a lower sense of wellbeing than those from two biological parents' households (King\& Lindstrom, 2017).

These studies used the term wellbeing in rather an ambiguous manner hence the current study focused specifically on self-esteem as a construct of psychosocial development. For instance King \& Thorsen (2015) researched on step families characteristics and adolescent perception of belonging to step families but did not find out how this perception affect adolescent selfesteem. According to Blessings(2014) children in blended families experience cognitive, emotional, behavioral and academic difficulties compared to children brought up in biological families; findings that Shui (2015) embraces but emphasizes that many studies examining blended families have dealt with cognitive, educational and psychological outcomes during child hood and adolescence. The current study looked at this void by addressing adolescents' self-esteem.

Willis \& Limb (2017) stated that step parent children attachment enhances adolescents stress level a finding that Jensen (2015) concurs with that step parent children relationships are stressful and have an effect on attachment outcomes on children. On the other hand Njoroge \& Kirori (2015) found out adolescents with delinquent behavior come from step mothers' families than within step fathers' families. This is in line with (Jensen \& Lippold,2019) findings that majority of the youth with delinquent behavior come from step family background but adds that $60 \%$ of such youths have a low self-esteem compared to those with a high self-esteem. Amato (2010) concurs with this view on adolescents experiencing behavioral difficulties in step family relationships. From the above studies it was evident that few studies had explored 


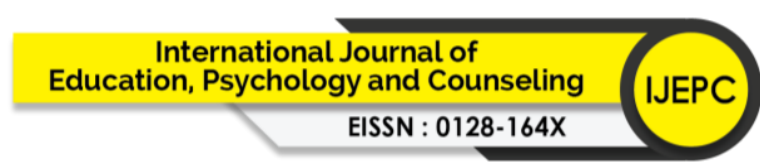

Volume 6 Issue 44 (December 2021) PP. 176-197

DOI 10.35631/IJEPC.644014

parental attachment and adolescent self-esteem development and this study was therefore significance.

\section{Research Methodology}

\section{Sample Size and Sampling Design}

Sampling is a process of selecting a number of individuals or objects from a population such that the selected group contains elements representative of the characteristics found in the entire group (Kombo \& Tromp, 2013).

The study employed multistage sampling technique comprising of simple random sampling, survey method of sampling, purposive sampling and also inclusive/exclusive criteria. Simple random sampling was used to sample 3 Sub Counties these were; Limuru, Thika, and Kiambaa out of the 12 sub counties in Kiambu County.

Orodho (2013) state that a representative sample ought to constitute at least $30 \%$ of the population when the population of the study is small and $10 \%$ if the population is large. In order to acquire a fair representation of sub counties a sampling index of $0.3(30 \%)$ was used to select the 3 sub counties. In addition lists of all public secondary schools in the three sub counties were obtained from the respective education offices in Kiambu County and simple random sampling was used to select a total of 9 schools from the 3 sub counties.

The second stage entailed selecting students to be included in the study. Survey sampling technique was adopted because the total population of adolescents that came from blended families was unknown. Prior to the actual data collection day the researcher visited the 9 sampled schools to determine the population of adolescents from blended families with the assistance of school counselors. Simple random sampling was used to determine the 5 classes to be sampled in each of the 9 schools. The 5 classes had a population of 55 students each. A short questionnaire with demographic data of students was issued to all the students (2475) in a bid to elicit the adolescents from the said classes that came from blended families in the 9 schools. A total number of 208 adolescents from blended families in the 9 schools was elicited and this was considered a sufficient sample size. In Marriage and Family research studies, a sample size of between 150 to 200 is enough for a study (Sprenkle \& Piercy, 2005). All the 208 students were issued with questionnaires based on the standardized tools. The inclusion/exclusion criteria was;

i) The students were 13-19 years of age

ii) The student should be from a blended family household where one of the parent was either a step father or a step mother.

The third stage of the sampling process involved selecting of focus group members and school counselors. Simple random sampling was used to sample 24 participants to form 4 focus groups comprising of 6 participants each (Johnson \& Christen, 2004). 4 focus groups were purposively selected from 4 of the 9 sampled schools this is consistent with (Leech \& Zoran, 2007) who recommended that 3 to 6 groups are adequate to bring out most prevalent themes within any given data set. Two of the focus groups comprised of females/ males who live with step mothers while the other two groups were comprised of female/ male students who reside with step fathers. The focus groups members were grouped as homogenous groups to enhance 


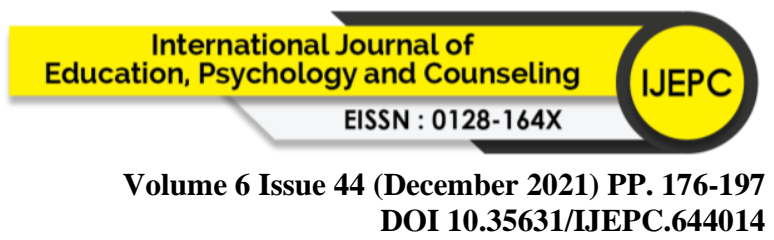

communication. Also 4 counselors were purposively selected from the 9 schools for in-depth interview schedule. The counselors were purposively sampled to elicit professional counselors because not all counselors in schools are normally trained in counselling.

\section{Findings and Discussions}

\section{Descriptive of Self-Esteem as Dependent Variable}

The dependent variable self-esteem was measured by Rosenberg self-esteem scale (Rosenberg, 1969). The Rosenberg self-esteem scale has 10 questions measured in three likert scale; 0 to 3. The descriptive statistical tests conducted were Mean (M) and Standard deviation (SD). The mean value result for each question was categorized as follows: $\mathrm{M}<0.5$ as strongly disagreed, $\mathrm{M}=>0.5,<1.5$ as disagreed, $\mathrm{M}=>1.5,<2.5$ as agreed and lastly $\mathrm{M}=>2.5$ as strongly agreed. The result was divided into three clusters of parents; adolescents living with step father, the adolescents living with step mother and the combined (all parents) as presented in table 1.

Generally, adolescents rated most of the items on self-esteem as agreed $(\mathrm{M}=>1.5,<2.5)$. In chronological order, items ranked as agreed (rounded $\mathrm{M}=2$ ) were; 'I am able to do things that other people can do' $\mathrm{M}=2.24, \mathrm{SD}=.917$, 'As a person I feel I am worthy and at per with others' $\mathrm{M}=2.11, \mathrm{SD}=0.965$, 'I surely feel useless at times' $\mathrm{M}=1.99, \mathrm{SD}=1.064$, 'I am mostly satisfied with myself' $\mathrm{M}=1.96, \mathrm{SD}=1.033$, 'I feel I have a few good qualities' $\mathrm{M}=1.69, \mathrm{SD}=0.985$, 'I take a hopeful attitude towards myself' $\mathrm{M}=1.56, \mathrm{SD}=1.121$, and lastly, 'I feel I have little to be proud off' $\mathrm{M}=1.47, \mathrm{SD}=1.109$. Only three items were ranked as disagree (rounded $\mathrm{M}=1$ ); 'All things considered I am likely to feel I am a failure' $\mathrm{M}=1.08, \mathrm{SD}=0.956$, 'I hope I could have more respect for myself' $\mathrm{M}=0.70, \mathrm{SD}=.928$ and 'Sometimes I feel I am not good enough' $\mathrm{M}=0.56, \mathrm{SD}=.801$.

On comparing the self-esteem of the adolescents based on the type of their blended families, most of the items were rated as agreed $(M=2)$ by both adolescents living with step father and adolescents living with step mother. Only one item was rated by adolescent living with their step father as strongly agreed $(\mathrm{M}=4)$; 'I take a hopeful attitude towards myself' $(\mathrm{M}=3.54$, $\mathrm{SD}=.719$ ) but rated as agreed by adolescent living with their step mother. The items rated as disagreed by adolescents regardless of their step parents were; 'I hope I could have more respect for myself', 'I surely feel useless at times' and 'Sometimes I feel I am not good enough'.

Table 1: Mean and Standard Deviation for Self-Esteem

\begin{tabular}{|l|l|l|l|l|l|l|l|}
\hline & & \multicolumn{2}{|l|}{ Step Father } & \multicolumn{2}{l|}{ Step Mother } & \multicolumn{2}{l|}{} \\
\hline & & M & SD & M & SD & M & SD \\
\hline SE1 & $\begin{array}{l}\text { As a person I feel I am worthy and at } 2.11 \\
\text { per with others }\end{array}$ & 0.94 & 2.12 & 1.00 & 2.11 & 0.97 \\
\hline SE2 & I feel I have a few good qualities & 1.26 & 0.99 & 1.36 & 0.99 & 1.31 & 0.98 \\
\hline SE3 & $\begin{array}{l}\text { All things considered I am likely to feel } 1.92 \\
\text { I am a failure }\end{array}$ & 0.97 & 1.92 & 0.95 & 1.92 & 0.96 \\
\hline SE4 & $\begin{array}{l}\text { I am able to do things that other people } 2.18 \\
\text { can do }\end{array}$ & 0.97 & 2.32 & 0.83 & 2.24 & 0.92 \\
\hline SE5 & I feel I have little to be proud off & 1.28 & 1.10 & 1.72 & 1.08 & 1.47 & 1.11 \\
\hline
\end{tabular}


Volume 6 Issue 44 (December 2021) PP. 176-197 DOI 10.35631/IJEPC.644014

\begin{tabular}{|l|l|l|l|l|l|l|l|}
\hline SE6 & I take a hopeful attitude towards myself 1.42 & 1.14 & 1.47 & 1.10 & 1.44 & 1.12 \\
\hline SE7 & I am mostly satisfied with myself & 1.99 & 1.03 & 1.92 & 1.04 & 1.96 & 1.03 \\
\hline SE8 & $\begin{array}{l}\text { I hope I could have more respect for } \\
\text { myself }\end{array}$ & 0.63 & 0.89 & 0.80 & 0.97 & 0.70 & 0.93 \\
\hline SE9 & I surely feel useless at times & 1.96 & 1.09 & 2.04 & 1.03 & 1.99 & 1.06 \\
\hline SE10 & Sometimes I feel I am not good enough 2.52 & 0.72 & 2.33 & 0.89 & 2.44 & 0.80 \\
\hline
\end{tabular}

Using the computation of the Rosenberg, 1965 self- esteem scale, the summation of the respondents ranged from 0-30. From the summation, the self-esteem was categorized into three; low self-esteem, normal self-esteem and high self-esteem. The computation was modified from the original scale ranges of 0-30 with Scores between 15 and 25 are within normal range; scores below 15 as suggest low self-esteem and score above 25 as high selfesteem. Table 2, shows the distribution of the self-esteem of the respondents; $76.4 \%$ had normal self-esteem, $13 \%$ had low self-esteem and $10.6 \%$ had high self-esteem.

Table 2: Distribution on Self-Esteem

\begin{tabular}{|l|l|l|}
\hline & Frequency & Percent \\
\hline Low self esteem & 27 & 13 \\
\hline Normal self esteem & 159 & 76.4 \\
\hline High self esteem & 22 & 10.6 \\
\hline Total & 208 & 100 \\
\hline
\end{tabular}

\section{Findings and Discussions}

The study aimed at examining the influence of attachment Styles on adolescent self- esteem among secondary school students from blended families in Kiambu County. The self-esteem was measured by the use of Rosenberg, 1965 self- esteem scale, 10 questions tool (Rosenberg, 1965). For Scoring purposes the items are assigned a value to all of the 10 items as indicated below; firstly items 1, 2, 4,6,7: Strongly agree=3, Agree $=2$, Disagree= 1 and Strongly disagree $=0$. Secondly items 3, 5, 8, 9, 10 are reversed. Strongly agree $=0$, Agree $=1$, Disagree $=$ 2 and strongly disagree $=3$. The scores across the 10 items are added, the total scores should fall between 0 and 30. Higher numbers indicate high esteem while low numbers indicate low esteem. To answer the research question, the statistical analysis conducted were descriptive statistics, statistical assumption tests, correlation tests, T-test and ANOVA

\section{Correlation Test for Self-Esteem and Attachment Style}

Correlation test was conducted to test for significant relationship between the self-esteem as dependent variable and attachment style as the independent variable of study. Table 3 shows the correlation between attachment style components and adolescents self-esteem based on the step parents.

Adolescents had positive and significant relationship with all the attachment styles; parental trust $(r=.265, p<.05)$, parental communication $(r=.375, p<.05)$ and parental alienation $(r=-$ $.246, p<.05)$. On comparison with the step parent, adolescents with step fathers had statistical significant with parental trust $(r=.275, p<.05)$, parental communication $(r=.335, p<.05)$ but was not significant with parental alienation $(r=-.246, p>.05)$. Lastly, adolescents with step 
Volume 6 Issue 44 (December 2021) PP. 176-197

DOI 10.35631/IJEPC.644014

mothers had statistical significant with parental trust $(r=.257, p<.05)$, parental communication $(r=.431, p<.05)$ and parental alienation $(r=-.439)$.

Table 3: Correlation Test for Self-esteem and Attachment Style

\begin{tabular}{|l|l|l|l|l|}
\hline \multicolumn{5}{|c|}{ Self-esteem } \\
\hline \multirow{3}{*}{ Parental trust } & All Parents & step father & step mother \\
\hline \multirow{5}{*}{ Parental communication } & Pearson Correlation & $.265^{* *}$ & $.275^{* *}$ & $.257^{*}$ \\
\cline { 2 - 5 } & Sig. (2-tailed) & .000 & .002 & .016 \\
\cline { 2 - 5 } & $\mathrm{N}$ & 208 & 120 & 88 \\
\cline { 2 - 5 } & Pearson Correlation & $.375^{* *}$ & $.335^{* *}$ & $.431^{* *}$ \\
\cline { 2 - 5 } & Sig. (2-tailed) & .000 & .000 & .000 \\
\cline { 2 - 5 } & $\mathrm{N}$ & 208 & 120 & 88 \\
\hline Parental alienation & Pearson Correlation & $-.246^{* *}$ & -.070 & $-.439^{* *}$ \\
\cline { 2 - 5 } & Sig. (2-tailed) & .000 & .450 & .000 \\
\cline { 2 - 5 } & $\mathrm{N}$ & 208 & 120 & 88 \\
\hline \multirow{2}{*}{$* *$ Correlation is significant at the 0.01 level (2-tailed). } & & \\
\hline
\end{tabular}

\section{Mean and T-test on Self-Esteem and Attachment Style}

The mean comparison of the adolescents' self-esteem based on the step parent showed adolescents living with step mother had higher self-esteem $(\mathrm{M}=27.14, \mathrm{SD}=6.58)$ compared to those living with step father $(\mathrm{M}=26.81, \mathrm{SD}=5.42)$. Table 4 shows the mean of self-esteem.

Table Error! No text of specified style in document.: Mean of Self-Esteem and Step Parent

\begin{tabular}{|l|l|l|l|l|l|}
\hline & $\begin{array}{l}\text { step mother or } \\
\text { step father }\end{array}$ & N & Mean & Std. Deviation & $\begin{array}{l}\text { Std. Error } \\
\text { Mean }\end{array}$ \\
\hline \multirow{2}{*}{ Self-esteem } & Step Father & 120 & 26.8083 & 5.42372 & .49512 \\
& Step Mother & 88 & 27.1364 & 6.58312 & .70176 \\
\hline
\end{tabular}

However, a T-test result showed the mean difference on the self-esteem between adolescents living with step mother $(\mathrm{M}=27.14, \mathrm{SD}=6.58)$ compared to adolescents living with step father $(\mathrm{M}=26.81, \mathrm{SD}=5.42)$, was not statistically significant $t(206)=-.39, p>0.05$. This shows there was no significance difference on the self-esteem of adolescents based on their step parent.

Table 5 shows this result. 


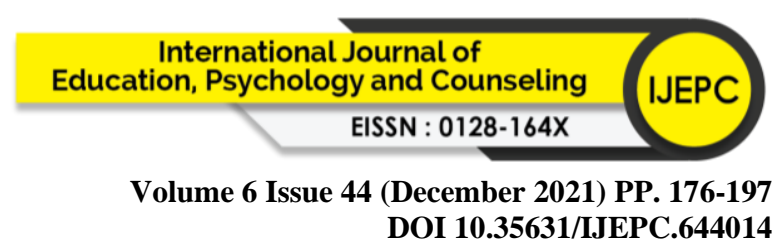

Table 5: 1T-Test for Self-Esteem and Step Parents

\begin{tabular}{|c|c|c|c|c|c|c|c|c|c|c|}
\hline & \multicolumn{2}{|c|}{$\begin{array}{l}\text { Levene's Test } \\
\text { for Equality of } \\
\text { Variances }\end{array}$} & \multicolumn{7}{|c|}{ t-test for Equality of Means } \\
\hline & & \multirow[t]{2}{*}{$\mathrm{F}$} & \multirow[t]{2}{*}{ Sig. } & \multirow[t]{2}{*}{$t$} & \multirow[t]{2}{*}{ df } & \multirow[t]{2}{*}{\begin{tabular}{|l} 
Sig. (2- \\
tailed)
\end{tabular}} & \multirow[t]{2}{*}{\begin{tabular}{|l|} 
Mean \\
Difference
\end{tabular}} & \multirow[t]{2}{*}{$\begin{array}{l}\text { Std. Error } \\
\text { Difference }\end{array}$} & \multicolumn{2}{|c|}{$\begin{array}{l}95 \% \\
\text { Confidence } \\
\text { Interval of the } \\
\text { Difference }\end{array}$} \\
\hline & & & & & & & & & Lower & Upper \\
\hline \multirow{2}{*}{$\begin{array}{l}\text { Self } \\
\text { esteem }\end{array}$} & $\begin{array}{l}\text { Equal } \\
\text { variances } \\
\text { assumed }\end{array}$ & 2.22 & 0.14 & -0.39 & 206.00 & 0.69 & -0.33 & 0.83 & -1.97 & 1.32 \\
\hline & $\begin{array}{l}\text { Equal } \\
\text { variances } \\
\text { not } \\
\text { assumed }\end{array}$ & & & -0.38 & 165.24 & 0.70 & -0.33 & 0.86 & -2.02 & 1.37 \\
\hline
\end{tabular}

The ANOVA was conducted to determine the statistical significance difference between the self-esteem and the attachment style (self-esteem * attachment style). As indicated on table 6, there was a statistically significant difference between attachment style components and selfesteem as indicated on one-way ANOVA; parental trust $(F(2,205)=3.659, p<.05)$, parental communication $(F(2,205)=9.721, p<.05)$ and parental alienation $(F(2,205)=8.549, p<.05)$.

Table 6: ANOVA on Influence of Attachment Style on Self-Esteem

\begin{tabular}{|c|c|c|c|c|c|c|}
\hline & & $\begin{array}{|ll|}\text { Sum } & \text { of } \\
\text { Squares } & \\
\end{array}$ & df & $\begin{array}{l}\text { Mean } \\
\text { Square }\end{array}$ & $\mathrm{F}$ & Sig. \\
\hline \multirow{3}{*}{ Parental trust } & $\begin{array}{l}\text { Between } \\
\text { Groups }\end{array}$ & 576.002 & 2 & 288.001 & 3.659 & .027 \\
\hline & $\begin{array}{l}\text { Within } \\
\text { Groups }\end{array}$ & 16134.416 & 205 & 78.704 & & \\
\hline & Total & 16710.418 & 207 & & & \\
\hline \multirow{3}{*}{$\begin{array}{l}\text { Parental } \\
\text { communication }\end{array}$} & $\begin{array}{l}\text { Between } \\
\text { Groups }\end{array}$ & 2129.802 & 2 & 1064.901 & 9.721 & .000 \\
\hline & $\begin{array}{l}\text { Within } \\
\text { Grouns }\end{array}$ & 22457.462 & 205 & 109.549 & & \\
\hline & Total & 24587.264 & 207 & & & \\
\hline \multirow{3}{*}{ Parental alienation } & $\begin{array}{l}\text { Between } \\
\text { Groups }\end{array}$ & 705.497 & & 352.748 & 8.549 & .000 \\
\hline & Within & 8458.580 & 205 & 41.261 & & \\
\hline & Total & 9164.077 & 207 & & & \\
\hline
\end{tabular}

A Tukey post hoc test revealed that Parental trust significantly influence an adolescent with high self-esteem $(\mathrm{M}=33.2, p<.05)$ and low self-esteem $(\mathrm{M}=26.8 p<.05)$ but not an adolescent with normal self-esteem $(p>.05)$. This shows parental trust as an attachment style has higher significant influence on adolescents' high self-esteem (33.2 \pm 7.9$)$ and adolescents' low selfesteem $(26.8 \pm 11.3)$ but not normal self-esteem. 


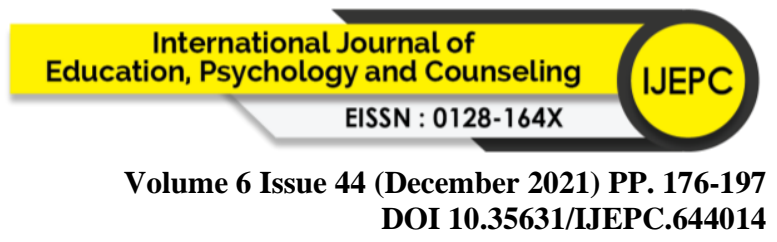

The second attachment style was Parental communication which statistically influenced adolescents level of self-esteem on all levels; high self-esteem $(\mathrm{M}=32.5, p<.05)$, Normal selfesteem $(\mathrm{M}=26.1, p<.05)$ and low self-esteem $(\mathrm{M}=19.3, p<.05)$. This shows parental communication as an attachment style has higher significant influence on adolescents' high self-esteem $(32.5 \pm 10.6)$, followed by normal self-esteem $(26.1 \pm 10.6)$ and the least influence was the low self-esteem $(19.3 \pm 9.5)$.

Lastly, the parental alienation as an attachment style was significant to adolescents at low selfesteem ( $M=20.9, p<.05)$, Normal self-esteem $(M=15.9, p<.05)$ and high self-esteem $(M=14.4$, $p$ <.05). However, it was not statistically significant difference on the level of influence between the normal self-esteem and high self-esteem $(p>.05)$. This shows parental alienation as parental attachment style has higher significant influence on adolescents' self-esteem chronologically from adolescent low self-esteem $(20.9 \pm 7.0)$, normal self-esteem $(16.0 \pm 6.3)$ and high self-esteem $(14.0 \pm 6.9)$. There was no statistically significant $(p>.05)$ difference on the way parental alienation influence normal self-esteem and high self-esteem. Table 7 shows this.

Table 7: ANOVA Tukey HSD on Influence of Attachment Style on Self-Esteem

\begin{tabular}{|c|c|c|c|c|c|c|c|}
\hline & \multirow[t]{2}{*}{$\begin{array}{l}\text { (I) SE } \\
\text { categorized }\end{array}$} & \multirow[t]{2}{*}{$\begin{array}{l}(\mathrm{J}) \text { SE } \\
\text { categorized }\end{array}$} & \multirow{2}{*}{$\begin{array}{l}\text { Mean } \\
\text { Difference } \\
(\mathrm{I}-\mathrm{J})\end{array}$} & \multirow[t]{2}{*}{$\begin{array}{l}\text { Std. } \\
\text { Error }\end{array}$} & \multirow[t]{2}{*}{ Sig. } & \multicolumn{2}{|c|}{$\begin{array}{ll}95 \% & \text { Confidence } \\
\text { Interval } & \end{array}$} \\
\hline & & & & & & $\begin{array}{l}\text { Lower } \\
\text { Bound } \\
\end{array}$ & $\begin{array}{l}\text { Upper } \\
\text { Bound } \\
\end{array}$ \\
\hline \multirow{6}{*}{ Parental trust } & \multirow{2}{*}{$\begin{array}{ll}\text { Low } & \text { self } \\
\text { esteem } & \end{array}$} & $\begin{array}{ll}\begin{array}{l}\text { Normal } \\
\text { esteem }\end{array} & \text { self } \\
\end{array}$ & $-4.36129^{*}$ & 1.84661 & .050 & -8.7209 & -.0017 \\
\hline & & $\begin{array}{ll}\begin{array}{l}\text { High } \\
\text { esteem }\end{array} & \text { self } \\
\end{array}$ & $-6.36700^{*}$ & 2.54803 & .035 & -12.3826 & -.3515 \\
\hline & \multirow{2}{*}{$\begin{array}{l}\text { Normal self } \\
\text { esteem }\end{array}$} & \begin{tabular}{|lr}
$\begin{array}{l}\text { Low } \\
\text { esteem }\end{array}$ & self \\
\end{tabular} & $4.36129^{*}$ & 1.84661 & .050 & .0017 & 8.7209 \\
\hline & & $\begin{array}{ll}\begin{array}{l}\text { High } \\
\text { esteem }\end{array} & \text { self } \\
\end{array}$ & -2.00572 & 2.01804 & .582 & -6.7700 & 2.7586 \\
\hline & \multirow{2}{*}{$\begin{array}{ll}\text { High } & \text { self } \\
\text { esteem } & \end{array}$} & \begin{tabular}{|ll}
$\begin{array}{l}\text { Low } \\
\text { esteem }\end{array}$ & self \\
\end{tabular} & $6.36700^{*}$ & 2.54803 & .035 & .3515 & 12.3826 \\
\hline & & \begin{tabular}{|ll}
$\begin{array}{l}\text { Normal } \\
\text { esteem }\end{array}$ & self \\
\end{tabular} & 2.00572 & 2.01804 & .582 & -2.7586 & 6.7700 \\
\hline \multirow{6}{*}{$\begin{array}{l}\text { Parental } \\
\text { communication }\end{array}$} & \multirow{2}{*}{$\begin{array}{ll}\text { Low } & \text { self } \\
\text { esteem } & \end{array}$} & \begin{tabular}{|lr}
$\begin{array}{l}\text { Normal } \\
\text { esteem }\end{array}$ & self \\
\end{tabular} & $-6.77987^{*}$ & 2.17861 & .006 & -11.9233 & -1.6365 \\
\hline & & \begin{tabular}{|ll}
$\begin{array}{l}\text { High } \\
\text { esteem }\end{array}$ & self \\
\end{tabular} & $-13.16667^{*}$ & 3.00613 & .000 & -20.2637 & -6.0696 \\
\hline & \multirow{2}{*}{$\begin{array}{l}\text { Normal self } \\
\text { esteem }\end{array}$} & \begin{tabular}{|lr}
$\begin{array}{l}\text { Low } \\
\text { esteem }\end{array}$ & self \\
\end{tabular} & $6.77987^{*}$ & 2.17861 & .006 & 1.6365 & 11.9233 \\
\hline & & \begin{tabular}{|ll}
$\begin{array}{l}\text { High } \\
\text { esteem }\end{array}$ & self \\
\end{tabular} & $-6.38679^{*}$ & 2.38085 & .021 & -12.0077 & -.7659 \\
\hline & \multirow{2}{*}{$\begin{array}{l}\text { High } \\
\text { esteem }\end{array}$} & \begin{tabular}{|lr}
$\begin{array}{l}\text { Low } \\
\text { esteem }\end{array}$ & self \\
\end{tabular} & $13.16667^{*}$ & 3.00613 & .000 & 6.0696 & 20.2637 \\
\hline & & \begin{tabular}{|ll}
$\begin{array}{l}\text { Normal } \\
\text { esteem }\end{array}$ & self \\
\end{tabular} & $6.38679^{*}$ & 2.38085 & .021 & .7659 & 12.0077 \\
\hline
\end{tabular}


Volume 6 Issue 44 (December 2021) PP. 176-197

DOI 10.35631/IJEPC.644014

\begin{tabular}{|c|c|c|c|c|c|c|c|}
\hline \multirow{6}{*}{$\begin{array}{l}\text { Parental } \\
\text { alienation }\end{array}$} & \multirow{2}{*}{$\begin{array}{ll}\text { Low } & \text { self } \\
\text { esteem } & \end{array}$} & $\begin{array}{l}\text { Normal self } \\
\text { esteem }\end{array}$ & $4.96366^{*}$ & 1.33705 & .001 & 1.8071 & 8.1203 \\
\hline & & $\begin{array}{ll}\begin{array}{l}\text { High } \\
\text { esteem }\end{array} & \text { self } \\
\end{array}$ & $6.88047^{*}$ & 1.84492 & .001 & 2.5249 & 11.2361 \\
\hline & \multirow{2}{*}{$\begin{array}{l}\text { Normal } \\
\text { esteem }\end{array}$} & $\begin{array}{ll}\begin{array}{l}\text { Low } \\
\text { esteem }\end{array} & \text { self } \\
\end{array}$ & $-4.96366^{*}$ & 1.33705 & .001 & -8.1203 & -1.8071 \\
\hline & & $\begin{array}{ll}\begin{array}{l}\text { High } \\
\text { esteem }\end{array} & \text { self } \\
\end{array}$ & 1.91681 & 1.46117 & .390 & -1.5328 & 5.3664 \\
\hline & \multirow{2}{*}{$\begin{array}{l}\text { High } \\
\text { esteem }\end{array}$} & $\begin{array}{ll}\begin{array}{l}\text { Low } \\
\text { esteem }\end{array} & \text { self } \\
\end{array}$ & $-6.88047^{*}$ & 1.84492 & .001 & -11.2361 & -2.5249 \\
\hline & & $\begin{array}{l}\text { Normal self } \\
\text { esteem }\end{array}$ & -1.91681 & 1.46117 & .390 & -5.3664 & 1.5328 \\
\hline
\end{tabular}

*. The mean difference is significant at the 0.05 level.

Statistical analysis conducted were; descriptive statistics, statistical assumption tests, Correlation tests, T- test and ANOVA and Narrative analysis. The ANOVA was conducted to determine the statistical significance difference between self-esteem and the attachment style. Findings indicated there was a statistically significant difference between attachment style components and self-esteem. Further, a Tukey post hoc test revealed that parental trust as an attachment style has higher significant influence on adolescents' high self-esteem and adolescents' low self-esteem but not normal self-esteem. It was also noted parental communication as an attachment style had higher significant influence on adolescents' high self-esteem followed by normal self-esteem and the least influence was the low self-esteem. Lastly, parental alienation as parental attachment style had higher significant influence on adolescents' self-esteem chronologically from adolescent low self-esteem normal self-esteem and high self-esteem. There was no statistically significant difference on the way parental alienation influence normal self-esteem and high self-esteem.

The above findings are in line with Studies carried out by Mónaco (2019) among Spanish adolescents that indicated that adolescents who form an intimate bond of trust with their care givers, report high positive affect, lower stress levels, greater life satisfaction and a strong selfesteem. In contrast, adolescents with insecure attachment with primary care givers are likely to experience challenges in regulating emotions, experience low self- esteem and are more prone to engage in negative behaviour (Monacco \& Castilla, 2019). Similarly the study indicated that step parents that have secure relationships with adolescents where there is trust and appropriate communication such adolescents develop a high self- esteem as depicted by the (Respondent FGD I, Respondent FGD 6). "I have a good relationship with my step father even if he is not my real father and this has increased my level of self-esteem". (Respondent FGD1). Another respondent retaliated; "Before my step dad came into my life I had a low selfesteem because I had no relationship with my biological mother. My step father has raised my self -esteem by inspiring me to achieve great heights especially in academics. I am working hard so that I can pass my examination and pursue Medicine and Surgery at the University of Nairobi. My step dad is my hero". (Respondent FGD 6). Similarly a study done on teenagers from China, Germany, Australia and United States as well as Dutch, Turkish, Moroccan and Surinamese adolescents residing in Netherlands indicated that a close intimate teenager parent connection predicted self-esteem (Harris, 2015; Wang \& Sheikh, 2014). On the contrary findings indicated that step parents who adopt insecure attachment styles are distant with adolescents and this enhance low self- esteem in the step adolescents as depicted by Copyright (C) GLOBAL ACADEMIC EXCELLENCE (M) SDN BHD - All rights reserved 


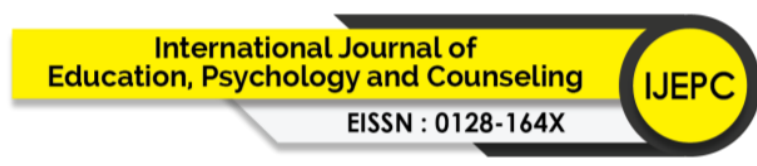

Volume 6 Issue 44 (December 2021) PP. 176-197

DOI 10.35631/IJEPC.644014

(Respondent FGD18). "My mother treats me like a house maid and this makes me feel sad and low". Similarly, a counsellor quoted an adolescent who said;" I despise my step father because he always compares my academic performance with that of my step siblings and calls me a failure and this has lowered myself esteem" (counsellor 4). Likewise, Rosen (2016) supported the above notion that showed that insecure adolescents had a low self-esteem than the secure group. From the above it is clear that parent involvement and parenting attachment styles are very important in adolescent self-esteem development regardless of whether adolescents come from step or biological families. It is therefore important for step parents to adopt a secure attachment style that results to close relationships with adolescents and thereby enhance their self- esteem. Insecure attachment styles is detrimental to adolescent self- esteem.

Findings from the study indicated that daughters whose step fathers were present in their lives and had a secure attachment had high self- esteem as depicted by (Respondent FGD 6). "Before my step dad came into my life I had a low self-esteem because I had no relationship with my biological mother. My step father has raised my self-esteem by inspiring me to achieve great heights especially in academics. I am working hard so that I can pass my examination and pursue Medicine and Surgery at the University of Nairobi. My step dad is my hero". (Respondent FGD6). On the contrary step fathers were noted to have a challenging relationship with step sons and this has impacted negatively on their self-esteem. (Respondent FGD 9 , Counsellor) support this assertion ; "I used to come home from visiting friends as late as $7 \mathrm{pm}$ when I was not in school and my biological mother was okay with it but when she was married, my step father told me that I should not report home later than 5:30 pm. An argument arose and he slapped me in the presence of my younger step sibling and I felt angry and very low". This findings indicate that secure attachment styles enhance high- self- esteem as compared to those step parents who adopt insecure attachment styles that result in low self-esteem. It also underscores the role played by step fathers in enhancing their step daughters' high self-esteem and a call to them to improve on their relationship with step sons. Similarly earlier studies noted that daughters who perceived their fathers in a positive light also depicted high selfesteem than those who did not (All good et al., 2012).

The study findings also showed that early step mother child secure attachment right from childhood enhances adolescent self-esteem as noted from response given by (Respondent FGD 4) "My step mother brought me up since I was young after my biological mother abandoned my younger brother and I. I am not her biological son but she loved and treated me so well and never mistreated me, I believe she contributed in building my self-esteem as I grew up". This was in line with Keizer (2019) studies that indicated that mother- child attachment are associated with higher levels of self-esteem for both adolescents' sons and daughters These findings are similar to Bowlby's theory (Bowlby, 1971) that healthy relationships that adolescents have with parents are a manifestation of appropriate development . Therefore, the study findings brought to the fore that attachment styles adopted by step parents influence adolescent self- esteem. Step parents that adopt secure attachment style enhance adolescent high self -esteem while adolescents whose parents adopt insecure attachment have low selfesteem. It was noted that most the girls had a difficult relationship with their step mothers which leads to low self- esteem unlike with the step fathers. The participants reported that they are overworked and step mothers taint them badly to their biological fathers leading to a strenuous relationship with the biological fathers. "My mother treats me like a house maid and I feel angry and low". (Respondent FGD 18). This contrasts empirical studies that found out 


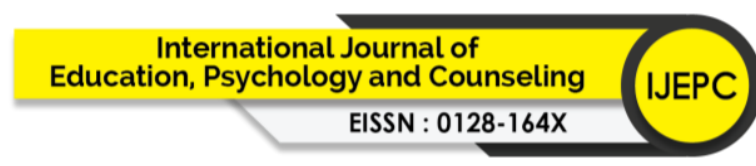

Volume 6 Issue 44 (December 2021) PP. 176-197

DOI 10.35631/IJEPC.644014

that adolescent daughters report high quality attachment to both parents than adolescents sons (Zia et al., 2015).

Most of the participants noted their step parents were discriminative when it came to discipline issues and this was demoralizing. Participants stated that each step parent supported their biological children most of the time at the expense of the step children even when the latter were on the wrong. Other participants felt that when on the wrong, their biological parents punished them but when step siblings are in disciplined they do not seem to care much about them. They wondered why there is so much disagreement and hatred among step siblings and why parents take sides instead of treating all parties equally. "I remember a day my biological mother beat me senseless for having slept out, yet my elder step sister had sleep overs many times but my mother never bothered. I felt devastated and this really lowered my self-esteem". (Respondent FGD 24). This assertion concurs with King\& Lindstorm (2017) that children in blended families have a low sense of wellbeing than those from two biological parent households. This depicts how crucial it is for step parents to treat all children fairly regardless of whether they are biological or step children in order to enhance their self- esteem.

Participants disliked the way step parents come to their household and change the rules of the house and expect the step children to follow the rules. They stated that before the step parents joined their households they had their own tradition of doing things for instance; what to cook, where to eat from, time to come back home after visiting friends and who to visit. They hated the way the step parents introduced their own rules without their consent yet they are the strangers in the household and should in actual sense follow the rules of the household they join. "I used to come home from visiting friends as late as $7 \mathrm{pm}$ when I was not in school and my biological mother was okay with it but when she was married my step father told me that I should not report home later than 5:30 pm. An argument arose and he slapped me in the presence of my younger step sibling and I felt sad and very low". (Respondent FGD 9). His step siblings keep reminding him of that incidence and this lowers his esteem. He has become his step father's worst enemy and often tells the biological mother to quit the marriage for his sake. It was also noted that step parents compare their biological children academic performance to that of step children and it does not matter the level of education their children are and this lowers the self- esteem of the step children. "You are in form 3 and your performance in mathematics is terrible a grade D- is just bad. Why don't you score an 'A' grade like John who defeats all standard 5 pupils in his class? You better pull up your socks". (Respondent FGD 20). This is also affirmed by Kin \& Lindstrom (2017) assertion that children in blended families have a lower sense of wellbeing than those from two biological parent house hold.

It emerged from the study that some male participants have minimal relationship with either their step mothers or biological fathers and they often miss their biological mothers and feel empty. Some reach out to these mothers secretly since their biological fathers have warned them not to communicate with their biological mothers. In some other instances few biological sons have gone to visit their mothers where they are currently married and the men who married them have been very hostile to them for no apparent reason. This hostility has made them feel unwanted and worthless. "Next time you set your feet in this house in pretence of checking on your mother I will teach you a lesson get out and leave". (Respondent FGD 11). In other instances biological parents insult their children when they insist they want to visit the other biological parent. They are instructed not to ever communicate to useless good for nothing 


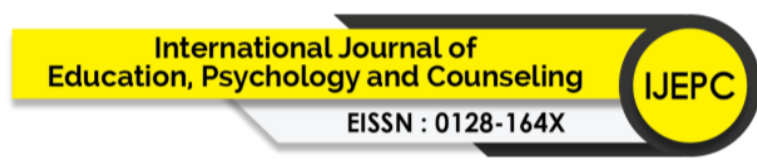

Volume 6 Issue 44 (December 2021) PP. 176-197

DOI 10.35631/IJEPC.644014

parent that abandoned them, this angers the adolescent who craves to meet and reunite with this parent, resulting to low self- esteem. "Your father does not pay your school fees and does not feed you why do you want to visit him anyway? Why look for someone who abandoned you and mistreated me? You are such a disgrace". (Respondent FGD 2). A few participants felt betrayed by the biological parent who does not live with them. Some felt they were a burden to them, or they got tired of them and others felt they may have been the cause of their parent separation. These makes them feel stressed, unworthy and rejected. It is worse if the step parents become hostile which was the case to most of the participants. They keep wondering why some parents chose to leave them behind and disown them yet their names still appear in their birth certificate and in school as parents but they are nowhere to be seen. This study brings to the fore that adolescents should be allowed to access the other biological parent regardless of whether they are living in the same household or not. The biological parent who does not leave with the biological children should also reach out to them although they have separated with the spouse.

Study findings indicated that inappropriate co-parenting between the biological parents lowers adolescent self- esteem. It was noted that participants have issues of payment of school fees, shopping and pocket money because the biological parents disagree who should support them in the said areas. It was noted they get devastated when their names keep appearing in the list of students whose parents default school fees payment. Sometimes the school principals melt their frustrations to them as if they are responsible for their school fees payment. They get frustrated when one biological parent asks them to call the other and inform them on the support they require. "I hate the way my biological mother keeps asking me to call my real father so that he pays my school fees or shop for me. In addition, students in my school know that I struggle with school fees payment because I am often sent home for lack of school fees. Other times my shopping is over before the term ends and they assist me because I am a needy student yet I have parents who can meet these needs. This makes me feel unwanted, sad most of the times and rejected. This has made me have a low self-esteem and a distant relationship with my biological parents" (Respondent FGD 15). This underscores the importance of appropriate co-parenting between the biological parents.

Participants in the FGD agreed that there is sibling rivalry with the step siblings as well as the mutual siblings. They felt that these children are favoured and they have a better relationship with their parents. It was noted that step children are given more attention and this strain relationships in the house hold. Most of them felt it is difficult to live with step sibling and wished they would leave with their step parent. Some stated how they experience loneliness because their biological mothers are busy with mutual children and forget about them. The girls who were the last born in their biological families before their fathers re married felt that mutual children took their positions as the last born and these makes them despise them. The fact that all the love and attention they initially enjoyed as the last born was transferred to these children makes them dislike them. It is worse if the step children happen to be in the same age bracket especially in the adolescent stage. There are constant arguments and there are times when they take sides against each other. These complications of relationships lead to participants low self- esteem. Most participants said the step parents should treat all the children equally. "My biological mother forgot about me and when I complain she asks me if I want her to abandon my younger step siblings (mutual) so that she can take care of me on the other hand my step father sarcastically tells me to grown up". (Respondent FGD 21). 


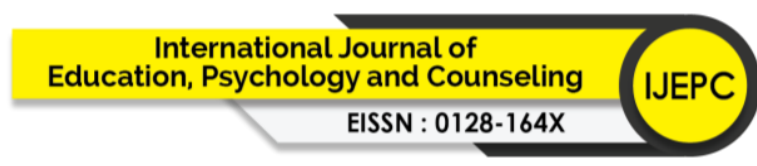

Volume 6 Issue 44 (December 2021) PP. 176-197

DOI 10.35631/IJEPC.644014

Most of the participants felt their biological parents never explained to them about remarriage especially if the step parents joined their house hold when they were adolescents. They wondered how a step parent become part of the family without their knowledge. Some said that these step parents would be spotted with their biological parents once in a while then all of a sudden they join the family. It was also noted that their biological parent expects them to call them dad or mum which they find impossible. Some participants felt their biological parents remarried so fast and feel they betrayed the other parent. These step parents come in with new demands and forget they are total strangers. Some of the participants felt the step children intruded their privacy, by sharing their bedrooms, others felt the house was too full and the environment was not conducive any more. When they raised their concern the biological parent reprimands them and concludes they are out to ruin their relationship with the step parent and their children. They often find themselves on the receiving end and this makes them frustrated and it affects their self- esteem.

From the data it was noted that some participants struggle in relating to their new step parent because they had not completely healed from their real parents separation. They were not ready to accept a step parent especially because their other parent is alive and many times they are uncertain of how to behave around the stranger and the step children. So when they are reprimanded for behaving contrary they get hurt and withdraw or avoid any interactions with the family members. It was noted that those participants whose step parents joined the families when they were younger did not have many issues with the step parent. They learnt to address them as father or mother and this has not changed even at the point they discovered they were not their biological parents. Actually some agreed that step parents raised their self- esteem as affirmed by (Respondent FGD 1). "I have a good relationship with my step father even if he is not my real father and this has increased my level of self-esteem.

\section{Conclusions}

The study concludes that; step parents that have a close relationship with adolescents where there is trust and appropriate communication such adolescents develop a high self -esteem. On the contrary those step parents who adopt insecure attachment styles have a distance relationship with adolescent and this enhances development of low self- esteem. Step fathers that adopt a secure attachment with step daughters and are present in their lives enhance their high self- esteem as compared to those step fathers that distant themselves from their step daughters. Step fathers were noted to have insecure relationships with step sons and this contribute to such adolescents developing a low self-esteem. Early step mother child attachment enhances adolescent self -esteem during adolescent stage. The study therefore concludes that step parents attachment styles influence adolescent self- esteem trust component.

\section{Recommendations}

These recommendations are made to benefit Ministry of Education, counselors, parents, families and society at large.

\section{Ministry of Education}

Should have mechanisms in place that caters for unique needs of adolescents. The Ministry should deliberately institute a counselling division within its structures with representations at all levels from the headquarters all the way to the individual schools. This counselling divisions should be empowered through appropriate and adequate human and material resources to carry 


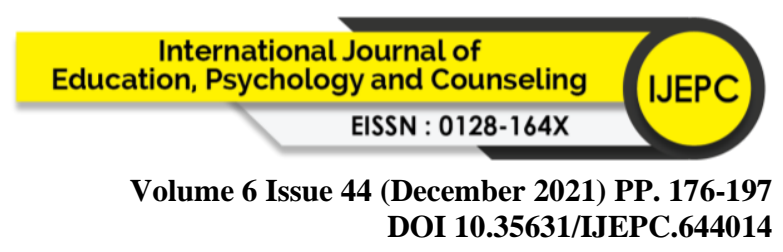

out its functions. As a bare minimum, the ministry should deploy trained counselors who are able to counsel adolescents' from blended families.

\section{Counselors}

School counselors should be appropriately trained and sensitized on the need to look out for issues pertaining to adolescents from blended families as opposed to the general school fraternity. This is because from the research findings adolescents from blended families encounter many challenges that affect their psychosocial development compared to adolescents living with both biological parents.

\section{Parents, Families And Society}

Should embrace the aspect of blended families in order to build healthy families and society at large. Step parents should embrace step children as early as possible after joining the blended families so as to enhance their establishment of self-esteem identity styles and emotional autonomy development. In addition, they should be psycho educated on the unique aspects of blended families. Parents should look into adolescence sense of safety and their freedom which can contribute to behavior problems.

\section{References}

Adams, G. R., \& Fitch, S. A. (2001). Ego stage and identity status development: A consequential analysis. Journal of Personality and Social psychology, 43, 574-583.

Ainsworth, M., Blehar, C., Waters, E., Wall, S. (1978) Patterns of attachment: A psychological study of the strange situation. Oxford, England: Lawrence Erlbaum

Alecka, M., Nycz M., S. Korskal. Topolenska, E. (2019). Change and consistency of self esteem in early and middle adolescence in the context of school transition. Journal of youth and adolescence. 48 (8), 1605-1608. https://doi.10.1007/5510964-019-01041-y

Allen, J., Grande, L., Tan, J.,Loab, E.(2018). Parent and peer predictors of attachment security from adolescence to adulthood. Journal of Child Development, 84(4), 11201132.https://doi:101111/cdev.12840

Allgood, S. M., Beckert, T. E., \& Peterson, C. (2012). The role of father involvement in the perceived psychological well being of young adult daughters: A retrospective study. North American Journal of psychology, 14 (1), 95-100.

Amato, P. R. (2010). Reserch in divorce: Continuing trends and new developments. JournalofMarriageandFamily,72(3),650666.https://doi.org/10.11111j1741373

Amato, P.R. (2010). Research on divorce continuing trends and new developments. Journal of marriage and family, 72(3),650-666. https://doi:10.1111/j1741-3737,2010.00723.xrv

Anggraeni, P. (2019). The role of attachment to mother and self-esteem towards aggressive behaviour in Depok City Indonesia: Jounal of Clinical Psychology, Gunadarma, University,Indonesia 2321-6379.

Anderson, B. (2000). Viewing the parent as a person: An individual related phenomeno. Student work.310http//digital commons.

Andrea, S., Mathias, A., Richard, R., Helmut, F. (2014). Low and decreasing self-esteem during adolescence predict adult depression two decades later. Journal of Family and societies, 36(6), 1413-1547

Andrea, S., Mathias, A., Richard, R,. Helmut, F. (2014), low and decreasing self-esteem during adolescence predict adult depression two decades later. 


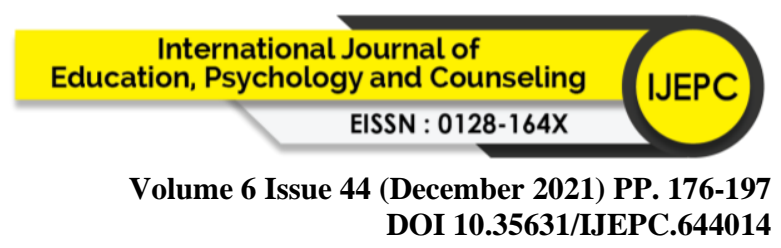

Bachman, J. Malley, P., Freedman. P., Donnellan, B. (2011). Adollescent self-esteem : Differences by race, ethnicity, gender and age. Journal of National library medicine. 10(4): 445-473. https://doi:10.1080/152988610037945338

Beijersbergen MD, Juffer F, Bakermans-Kranenburg MJ, van Ijzendoorn MH. (2012) Remaining or becoming secure: Parental sensitive support predicts attachment continuity from infancy to adolescence in a longitudinal adoption study. Developmental Psychology. 48(5):1277-1282.

Benson, M. Mcwey, L., Ross, J. (2013). Parental attachment and peer relations in adolescence: A meta-analysis. Journal of research in human development, 3(1), 33-43 https://doi:org/10.1207/s/15427617rhd0301-4

Bowlby, J. (1969). Attachment and loss (Vol. 1). New York, NY: Basic Books, Inc.

Brenning, K. M. \& Braet, C. (2013). The motion regulation model of attachment: An emotion-specific approach. Journal of Personal Relationship, 20(1), 107-123.

Branje, S. (2018). Development of parent adolescent relationships: conflict interactions as a mechanism of change. Journal of child development perspectives, 12(3). https://doi.10.1111/cdev.12278

Bretherton, I., \& Munholland, K.A. (2008). Internal Working Models in Attachment Relationships. Elaborating a central construct in attachment theory In Cassidy \& P. R.

Brown, S. L., Manning, W. D., \& Stykes, J. B. (2015). Family Structure and Child Wellbeing: Integrating Family Complexity, Journal of Marriage and Family, 77(1), 177-190.

Brown, S.L., manning, W.D., \& styles J.B. (2015). Family structure and child wellbeing: Integrating family complexity. journal of marriage and family, 77,177190.http://doi:10.1111/jomf.12145

Brown, S.L., Manning, W.D., \& styles, J.B. (2015). Family structure and child well-being integrating family complexity. Journal of marriage and family, 77, 177-190. https://doi:1011111/jomf.12145

Chapman, A., Coleman, M., and Gunong, L. (2016) like my grandparents but not; A qualitative (investigation of skip generation step grandchild- step grandparents relationships. Journal of marriage and family, 78(3),634-643. http://doi:10.1111/jomf.12303

Cartwright, C., Gibson, K. (2017). step mothers perceptions and experiances of the wicked stepmother stereo type. Journal of family issues 39(7):0192513x1773904. http://doi:10.117710192513x17739049

Cartwright, C., \& Gibson, K. (2014). The effects of co-parenting relationships with ex-spouses on couples in step families. Family matters, (92), 18- 28.

Chacha, G. (2015). Blended Families: drama when Step-Kids, Parents Don't Get Along, Crazy Monday (hhtp://www.sde.co.ke/category/1/crazy-Monday) Retrieved on 27thDecember 2016

Choi, J. \& Jackson, A.P. (2012).Fathers' involvement and child behaviour problems in poor African American single-mother families. Children and Youth Services Review, 33, 698-704.

Comtois, K., Cyr, C., Pascuzzo, K, Lessard, M. (2013). Attachment theory in clinical work with students. Journal of child adolescence. Behanor, 1(11). https://doi.org/10.4172/2375/2375-4495.1000111

Cooke, J. J., Kochendorfer, L. L., Stuart, K. K., Koehn, A. A., Kerns, K. A.(2018). Parent child attachment and children experiences and regulation of emotions: A meta-analytic review.

Creswell J.W. (2014). Research Designs: Quantitative, Qualitative, and Mixed Methods Approach. (4 ${ }^{\text {th }}$ ed.). Thousand oak, CA.Sage

Copyright $\odot$ GLOBAL ACADEMIC EXCELLENCE (M) SDN BHD - All rights reserved 


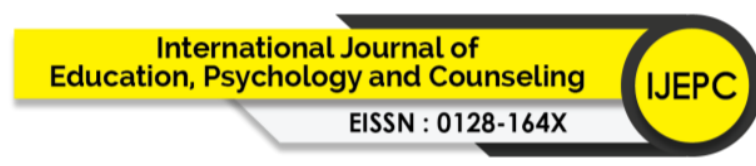

Volume 6 Issue 44 (December 2021) PP. 176-197

DOI 10.35631/IJEPC.644014

Crocetti, E., Shokri, O. (2010). Iranian validation of identity style inventory. International Journal of testing, 10(2), 185-199. https://doi.org/10.1080/1530050509035344696

CrocettI, E.,Erentaite, R., Zukguskiene, R. (2014). Identify styles, positive youth development and civic engagement in adolescence. Journal of youth adolescence, 43(11), https://doi:701007/s10964-014-0100-4.

Doinita, E., Maria, N. (2015). Attachment and parenting styles. Journal of Social and Behavioural Science, 203, 199-204.

Dollinger, G(2010). Scaling self-identity with respect to perceived social-cultural attitudes towards appearance and personality types among male and female adolescents in the age group of 16 to 25 years. The international journal of Indian psychology, 8(4) https://doi:10.25215/DIP:01/IF.3.9(ici)Du, H., King, R, Chi, P. (2017), self-esteem and subjective wellbeing restricted: The roles of personal, relational, and collective selfesteem. Journal of plus digital health, https://doi.org//10.1371/0183958

Dumas, T.M., Ellis, W.E. \& Wolfe.D.A. (2012).Identity Development as a buffer of Adolescent risk behaviours, in the context of peer group pressure and control. Journal of Adolescence, 35, 917-927 Du, H., King, R, Chi, P. (2017), self-esteem and subjective wellbeing restricted: The roles of personal, relational, and collective self-esteem. Journal of plus digital health, https://doi.org//10.1371/0183958

Eagleton, S. G., Williams, A. L., \& Merten, M. J. (2016). Perceived Behavioral Autonomy and Trajectories of Depressive Symptoms from Adolescence to Adulthood. Journal of Child and Family Studies. https://doi.org/10.1007/s10826-015-0201-z

Erdvic, I.B., Hangen, T. Ivarsonjnr, safvenbom, R, (2019). Global self worth among adolescents: the role of basic psychological need satisfaction in physical education. Scandinavian Journal of education Research, (64) https://doi.org/10.1080100313831.

Erozkan A., Dogan, U., Adiguzel, Adiguzel, A. (2016). Self efficiency, self esteem, and subjective hapiness of teacher candidates at the pedagogical formation certificate program. Journal of Education and Training Studies 4(8);72-82 https://doi:1011114/jets.v4i8.1535

Evans, J., \&Martin, F. (2015). Blended families. Datlas: Thomas Nelson, Inc.Extended, Uaps2015.priceton.edu/uploads/150718 Retrieved on27th December 2016

Frank-Nachmias C, Nachmias D. (2006). Reseach methods in the social science $s\left(6^{\text {th }}\right.$ ed). New York:Worth

Fogarty, K., Ferrer, M., \& McCrea, S. (2013). Couples Considering a Blended Family, University of Florida.

Follan, M. \& Minnis, H. (2010). Forty four juvenile thieves revisited. From Bowlby to reactive attachment disorder. Child, care, health and development, 36(5), 639-645. Doi: 101111/j.1365-2214.2009.01048.x

Ganong, L., Coleman, M., \& Jamison, T. (2011). Patterns of stepchild-stepparent relationship development. Journal of Marriage \& Family, 73(2), 396-413.

Ganong, L., Coleman, M,. \& jamisson, T., \& Fiestman, R. (2015). Divorced mothers coparental boundary maintenance after parents repartner. Journal of family psychology, 29(2), 221-231. https://doi:1011037/fam0000064

Gramaje, F., Garcia, F., Reyes, M., Serra, E., Garcia, F. (2019). Parenting styles and aggression in adolescents: Relationship with self-esteem and personal maladjustment. European Journal of Psychology Applied to legal Context, 12(1) 1-10.

Granquist, P., \& Sroufe, A., Dozier, M. (2017). Disorganized attachment styles: A review of the phenomenon and its implications for clinicians and policy. 


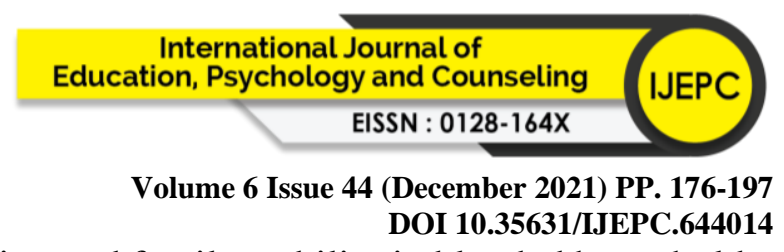

Irankunda, S., Sitawa, M. (2018). Child upbringing and family stability in blended households. A case of Gishosha commune, Bujumbura Province, Burundi. International Journal of social and development concerns, 4(17) 1JSDC

Jain, N. (2015). Father-Daughter Attachment Pattern and its Influence on Daughter's Development. The International Journal of Indian Psychology ISSN, 2(2), 2348-5396. http://www.ijip.in

Jensen. T., Lippold, M. (2019). Patterns of step relationship quality and adolescence short term and long term adjustment. Journal of family psychology, 32(8), 1130-1141. https://doi:10.1037/fam0000442.

Jensen, T.M., \& Howard, M.O.(2015). Perceived step parent-child relationship quality. A systmatic review of step children's perspectives. Marriage and family review, 99-153. https://doi: 10/1080/01494929.2015.1006717r

Jensen.T.M.Lommbardl,B.M., \& Larson,J.H.(2015). Adult attachment and step parenting issues: Couple relationship quality as a mediating factor. Journal of Divorce \& remarriage, 56(1),80-94. https// doi;10.10.1080/10502556.2015.972201R

Jensen,T.M; Shafer, K.(2015). Step family functionaryand closeness. Childrens views on second marriages and stepfathers relationships, social work, 58(2),127-1o a step family.36. https// doi10.1093/sw/swt007

Jensen, T. M., \& Harris, K. M. (2017). Stepfamily Relationship Quality and Stepchildren's Depression in Adolescence and Adulthood. Emerging Adulthood, 5(3), 191-203. https://doi.org/10.1177/2167696816669901

Jensen, T. M., Lippold, M. A., Mills-koonce, R., \& Fosco, G. M. (2019). Stepfamily Relationship Quality and Children's Internalizing and Externalizing Problems. 57(2), 477-495. https://doi.org/10.1111/famp.12284

Jensen, T. M., Shafer, K., \& Holmes, E. K. (2017). Transitioning to stepfamily life: the influence of closeness with biological parents and stepparents on children's stress. Child and Family Social Work, 22(1), 275-286. https://doi.org/10.1111/cfs.12237

Jensen,T. Pace, G. (2016). Step father involvement and stepfather child relationship quality: Race and parental marital status as moderators. Journal of marital ans Family Therapy, 42(4), 659-672. https://doi.org/10.1111jmft.12165.

Keizer, R. (2019). Perceived Quality of the Mother - Adolescent and Father - Adolescent Attachment Relationship and Adolescents' Self-Esteem. Journal of Youth and Adolescence, 1203-1217. https://doi.org/10.1007/s10964-019-01007-0

King, V., Boyd, L. M., \& Thorsen, M. L. (2015). Adolescents' Perceptions of Family Belonging in Stepfamilies. Journal of Marriage and Family, 77(3), 761-774. https://doi.org/10.1111/jomf.12181

King, V., Amato, P. R., \& Lindstrom, R. (2015). Stepfather-adolescent relationship quality during the first year of transitioning to a step family. Journal of Marriage and Family, 77, 1179-1189.

King,V , Amato. P.R.,\& Lindscom, R.(2015). Step-father- adolescent relationships quality during the first year of transitioning to a step family.Journal of marriage and Family. 77(5), 1179-1189. https// doi. 10.1111/jomf.12214

King,V \& Lindstrom,R.(2016). Continuity and change in step-father-step child closeness between adolescence and early adulthood. Journal of Marriage and Family, 78(3),730743.https//doi:10.1111/jomf.12281

King, V., Thorsen, M. L., \& Amato, P. R. (2014). Factors associated with positive relationships between stepfathers and adolescent stepchildren. Social Science Research, 47, 16-29. 


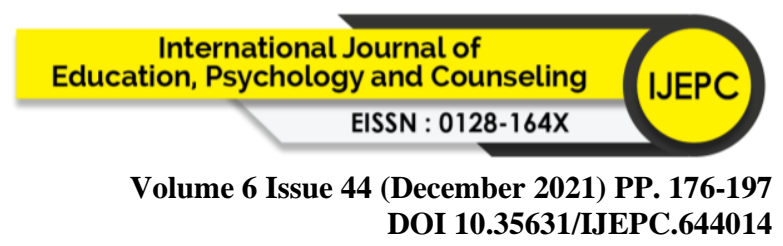

Kiralp, F. (2017). A study of students loneliness levels and their attachment styles. Journal of education and training studies, 5(7), 2324-205. https://doi:1/jets.redframe.com

Ksenija, K.(2016). Attachment to parents and friends as a context for development of self concept in adolescence: The personality traits as mediators. Journal of child and adolescence.https://doi.org/10.2298/ps11604335k.

Laible, Dr, Carlo, G., Roesch, S. (2005). Pathways to self-esteem in late adolescence. The role of parent and peer attatchment, empathy, and social behaviours, Journals of adolescence, 27(6), 703-16. https://doi.10.1016/j,adolescences.05.005.

Mónaco, E., Schoeps, K., \& Montoya-Castilla, I. (2019). Attachment styles and well-being in adolescents: How does emotional development affect this relationship? International Journal of Environmental Research and Public Health, 16(14). https://doi.org/10.3390/ijerph16142554

Njoroge, M. \& Kirori, G. (2018) Blended Family Dynamics and Academic Performance Outcome of the Child in Kenya: Case of Kabete Sub-County in Kiambu County. Journal of Culture, Society and Development Vol.41, 18

O'Connor, A., \& Boag, S. (2010). Do stepparents experience more parental antagonism than biological parents? A test of evolutionary and socialization perspectives. Journal of Divorce \& Remarriage, 51(8), 508-525.doi:10.1080/10502556.2010.504101

Pace, G. T., Shafer, K., Jensen, T. M., \& Larson, J. H. (2015). Step-parenting issues and relationship quality: The role of clear communication. Journal of Social Work, 15, 2444. doi: $10.1177 / 1468017313504508$

Pace, U., \& Zappulla, C. (2014). Relations Between Suicidal Ideation, Depression, and Emotional Autonomy from Parents in Adolescence. Journal of Child and Family Studies. https://doi.org/10.1007/s10826-010-9364-9

Pace, U. \& Zappulla, C. (2011). Problem behaviors in adolescence: The opposite role played by insecure attachment and commitment strength. Journal of Child \& Family Studies, 20,854-862. doi: 10.1007/s10826-011-9453-4

Rosen, H. M. (2016). Seeking Self-Certainty in an Uncertain Time: Attachment Style and SelfEsteem in Emerging Adulthood. Student Works, 10, 1-62. https://commons.clarku.edu/studentworks/10

Surman, C, H., Biederman, J. Spencer T., Miller, C.,McDermott. K., Faraone, S. (2013). Understanding deficient emotional self-regulation in adults with attention deficient hyperactivity disorder 5 (3); 2 73-81 https://doi:10.1007/512402-012-0100-8

Suzuki, H., Tomoda, A. (2015). Roles of attachment and self-esteem: Impact of early life sress on depressive symptoms among Japanese institutionalized children, BMC Psychiatry. https://doi.org/10.1186/s12888-015-0385-1.

Svenens, B., Wluyts, D, vansteen kiste, M., Mageau, G. A. (2015). Raising trophy kids. The role of mother's contingent self-esteem in material promotion. Journal of adolescence, 42, 40-49.

Wagnsson, S., Lindwall, M., Gustafsson, H. (2014). Participation in organised sport and selfesteem across adolescents; the mediating role of perceived sport competence. Journal of sport and exercise psychology, 36 (6), pp.584-594

Willis, B., \& Limb, G. E. (2016). The Impact of Stepfamily Adjustment on Adult Attachment: A Comparison of American Indians and Whites. Journal of indegenous Social Development, 5(2), 1-19

Young, R. E. (2013). The Influence of Parent-Child Attachment Relationships and SelfEsteem on Adolescents' Engagement in Risky Behaviors. Unpublished Master's Thesis, Brandeis University. 
Volume 6 Issue 44 (December 2021) PP. 176-197 DOI 10.35631/IJEPC.644014

Zia, A., Malik, A, Masoom, S. (2015). Father and daughter relationship and its impact on daughters self-esteem and academic achievement. Academic achievement on interdisciplinary studies, 41(1), pp311, https://doi:10.5901. 